\title{
Rana temporaria on Monti della Laga (Central Italy): isolated population or wide distribution? First record in Abruzzo and Marche
}

\author{
Francesco Di Toro ${ }^{1,2}$, Gianmarco Minuti ${ }^{3}$, Luca Coppari ${ }^{1,4}$, Matteo De Albentiss 5 , Paolo Laghi 6 , Dino Scar- \\ AVElli $^{7}$, VAlerio Ricciardi ${ }^{8}$, Giacomo BrUni ${ }^{4,9, *}$ \\ ${ }^{1}$ SHI sezione Abruzzo-Molise; c/o WWF Chieti - Pescara, Via Ortona SNC, Chieti, Italy \\ ${ }^{2}$ Gruppo Erpetologico Abruzzese e Molisano; c/o WWF Chieti - Pescara, Via Ortona SNC, Chieti, Italy \\ ${ }^{3}$ Department of Biology, Ecology \& Biodiversity Research Unit, Vrije Universiteit Brussels, Brussels, Belgium \\ ${ }^{4}$ SHI sezione Umbria-Marche; Perugia, Italy \\ ${ }^{5}$ Laboratory of Atmospheric Physics-Chemistry and Climatology (DiSPuTer), University “G. D’Annunzio" of Chieti-Pescara, Italy \\ ${ }^{6}$ Museo di Ecologia, Meldola (FC), Italy \\ ${ }^{7}$ Department of Veterinary Medical Sciences, Alma Mater Studiorum Università di Bologna, 40064 Ozzano dell'Emilia (BO), Italy \\ ${ }^{8}$ Via Monte Fascia 9, Roma, Italy \\ ${ }^{9}$ Commissione Atlante SHI \\ ${ }^{*}$ Corresponding author. E-mail: giacomo.b90@gmail.com
}

Submitted on: 2020, $29^{\text {th }}$ September; revised on: 2021, 10 $0^{\text {th }}$ March; accepted on: 2021, $8^{\text {th }}$ April

Editor: Marcello Mezzasalma

\begin{abstract}
In Central Italy Rana temporaria is only known to occur as a glacial relict on the eastern side of Monti della Laga (Lazio). In this study we report the presence of the species in other areas of the mountain chain, with documented sightings in five distinct localities in Marche and Abruzzo. We use these new records, together with other occurrence data from the Apennine chain, to generate a species distribution model and perform an analysis of the geological preference of the species in Central Italy. Although the model indicates a wide area of Marche and Abruzzo as suitable for R. temporaria, the actual distribution of the species in northern and central Apennine appears strongly associated with sandstones. Therefore, we argue that the presence of this geological substrate on Monti della Laga, but not in surrounding karst uplands, could be among the factors explaining its isolation. Our study aims at paving the way for future surveys and measures to protect these isolated populations from the threat posed by climate change.
\end{abstract}

Keywords. Rana temporaria, relict species, species distribution model, MaxEnt, Central Italy.

The common frog (Rana temporaria Linnaeus, 1758) is a monotypic Eurasian species particularly widespread in northern Europe (Gasc et al., 1997; Dufresnes et al., 2020). Adapted to cold climates, in its southern distribution the species is restricted to upland areas, reaching an altitude limit of c.a. $2800 \mathrm{~m}$ on the Alps (Tiberti and von Hardenberg, 2012). The southernmost limits of its range are located on the Pyrenees, in the Balkan Region and on the central Apennines (Gasc et al., 1997), where the species occurs mostly in fragmented mountain populations
(Bernini and Razzetti, 2006). Indeed, in Italy R. temporaria shows a continuous distribution throughout the Alps and the north-eastern Apennines, becoming more localized on the mountainous areas toward Central Italy, where it is only known to survive as a single isolated population on the uplands of Monti della Laga (Bernini and Razzetti, 2006; Stefani et al., 2012). This population is located in Lazio (Rieti Province), on the western side of the mountain chain, about $160 \mathrm{~km}$ from the last known occurrence on the northern Apennines (Berni- 
ni and Razzetti, 2006; Razzetti et al., 2007). The site lies between 1400 and $1600 \mathrm{~m}$ a.s.l. in the so called "Agro Nero", an area consistent with the ecological requirements of the species, including a mosaic of meadows and beech forests with streams, small lakes (Lago Secco and Lago Selva) and seasonal ponds and puddles that are used as breeding sites (Authors, pers. obs.). The population was reported in 1982 together with a sympatric population of another cold-adapted amphibian, the alpine newt Ichthyosaura alpestris apuana (Capula and Bagnoli, 1982). Therefore, R. temporaria on Monti della Laga is recognised as a glacial relict, which survived thanks to the favourable environmental conditions of the area (Stefani et al., 2012; Bartolini et al., 2014). However, when compared to the orographically continuous upland karst areas of Monti Sibillini (northward) and Gran Sasso massif (southward), Monti della Laga show a very distinct geology, characterized by sandstones and marls (Pellegrini, 2007). This compact substrate allows rainwater and meltwater to retain longer on the surface, thus favouring the formation of perennial springs and permanent or seasonal small wetlands, both in high-altitude grasslands and in beech forests at lower altitudes. Even though these geological features are common to the whole Monti della Laga chain, $R$. temporaria was not detected in other areas such as the eastern side, which belongs to Marche and Abruzzo regions (Posillico et al., 2017; Cameli et al., 2014). Recently, new observations for the species were made between 980 and $1130 \mathrm{~m}$ a.s.l. in the western side of Lazio (Bruni et al., 2016). In the present study we report the first record of Rana temporaria in Abruzzo and Marche, providing an habitat suitability analysis to evaluate its potential distribution in Central Italy and facilitate future research activities.

The new observations were made by the authors or collected through Citizen Science.

The individuals were photographed in situ and the coordinates and habitat information were recorded and integrated using the Habitat Map of the Gran Sasso Laga National Park (Bagnaia et al., 2015). The coordinates were projected on the $10-\mathrm{km}^{2}$ grid used in the Italian Atlas of Amphibians and Reptiles (Bernini and Razzetti, 2006) to detect the occurrence of the species in new squares.

Metamorphosed individuals were visually distinguished from congener species ( $R$. dalmatina and R. italica) according to a combination of morphological features (i.e. size, body proportions, shape of the snout, warts, dorsal, ventral and upper lip colouration), whereas larval stages were identified based on body morphology, col-

Table 1. Relevant data about the five new localities for Marche and Abruzzo; observation date is given as dd/mm/yyyy; locality names are followed by Municipality, Province and Region.

\begin{tabular}{|c|c|c|c|c|c|c|c|}
\hline Site & Date & Locality & $\begin{array}{l}\text { Coordinates } \\
\text { (Latitude / } \\
\text { Longitude) }\end{array}$ & $\begin{array}{l}\text { Altitude } \\
\text { (m a.s.1.) }\end{array}$ & UTM square & $\begin{array}{l}\text { Developmental stage; habitat, } \\
\text { CORINE biotopes code (Bagnaia et } \\
\text { al., 2015) }\end{array}$ & Observer \\
\hline 1 & $04 / 06 / 2015$ & $\begin{array}{c}\text { Monte Comunitore } \\
\text { (Arquata del Tronto, AP, } \\
\text { Marche) }\end{array}$ & $\begin{array}{l}42.731922 \mathrm{~N} \\
13.342084 \mathrm{E}\end{array}$ & 1607 & 33T UH63 & $\begin{array}{l}\text { tadpoles; seasonal pond in compact } \\
\text { grasslands of the Mediterranean } \\
\text { mountains to Nardus stricta and } \\
\text { related communities (code } 35.72 \text { ) }\end{array}$ & $\begin{array}{c}\text { Paolo Laghi and } \\
\text { Dino Scaravelli }\end{array}$ \\
\hline 2 & $22 / 08 / 2016$ & $\begin{array}{c}\text { Fosso Rio della Volpara } \\
\text { (Arquata del Tronto, AP, } \\
\text { Marche) }\end{array}$ & $\begin{array}{l}42.704861 \mathrm{~N} \\
13.369226 \mathrm{E}\end{array}$ & 1238 & 33T UH62 & $\begin{array}{l}1 \text { adult female; stream in beech } \\
\text { forests of southern and central } \\
\text { Europe (code 41.17) }\end{array}$ & Giovanni Rossi \\
\hline 3 & $07 / 07 / 2017$ & $\begin{array}{c}\text { Valle del Castellano } \\
\text { (Valle Castellana, TE, } \\
\text { Abruzzo) }\end{array}$ & $\begin{array}{l}42.683516 \mathrm{~N} \\
13.361997 \mathrm{E}\end{array}$ & 1772 & 33T UH62 & $\begin{array}{l}1 \text { adult (sex undetermined); stream } \\
\text { in compact grasslands of the } \\
\text { Mediterranean mountains to Nardus } \\
\text { stricta and related communities (code } \\
\text { 35.72) }\end{array}$ & $\begin{array}{l}\text { Matteo De } \\
\text { Albentiis }\end{array}$ \\
\hline 4 & $01 / 05 / 2019$ & $\begin{array}{c}\text { Fosso della Morricana } \\
\text { (Rocca Santa Maria, TE, } \\
\text { Abruzzo) }\end{array}$ & $\begin{array}{l}42.656455 \mathrm{~N} \\
13.397107 \mathrm{E}\end{array}$ & 1814 & 33T UH62 & $\begin{array}{l}1 \text { adult (sex undetermined); } \\
\text { stream in mid-European montane } \\
\text { siliceous cliffs (code 62.21), compact } \\
\text { grasslands of the Mediterranean } \\
\text { mountains to Nardus stricta and } \\
\text { related communities (code } 35.72 \text { ) }\end{array}$ & Giancarlo Tondi \\
\hline 5 & $\begin{array}{l}17 / 07 / 2020 \\
04 / 08 / 2020\end{array}$ & $\begin{array}{l}\text { Sorgente "Pane e Cacio" } \\
\text { (Campotosto, AQ, } \\
\text { Abruzzo) }\end{array}$ & $\begin{array}{l}42.573577 \mathrm{~N} \\
13.396734 \mathrm{E}\end{array}$ & 1796 & 33T UH61 & $\begin{array}{l}1 \text { subadult and } 1 \text { adult female; stream } \\
\text { in mid-European montane siliceous } \\
\text { cliffs (code } 62.21 \text { ), Blueberry heaths } \\
\text { of the Apennines (code } 31.4 \mathrm{~A} \text { ) }\end{array}$ & $\begin{array}{l}\text { Francesco Di } \\
\text { Toro and Valerio } \\
\text { Ricciardi }\end{array}$ \\
\hline
\end{tabular}


ouration and mouthparts (Razzetti et al., 2007; Ambrogio and Mezzadri, 2018).

In order to predict and prioritize locations for future search of $R$. temporaria in the area of interest, a habitat suitability map of the species was generated via maximum entropy modelling (MaxEnt 3.4.0; Phillips et al., 2006). The model focused on central and northern Apennines in order to include only the Apennine lineage of $R$. temporaria (Stefani et al., 2012). The presence-only data (49 occurrence points from Abruzzo, Marche, Lazio, Toscana, Emilia-Romagna, Piemonte and Liguria) used for building the model were gathered from personal records and public databases (GBIF, 2020). The complete dataset used for the analysis can be requested to the corresponding author. The environmental variables were selected among bioclimatic, topographic and ecological layers. Altitude, as well as 19 bioclimatic layers averaging the period 1970-2000, were downloaded from the WorldClim 2.1 database (https://www.worldclim.org). Aspect, slope, and distance from water sources were calculated in QGIS 3.12 (http://www.qgis.org/). Ecological layers included vegetation (percent tree cover) and land cover class (https://globalmaps.github.io). All layers featured a 30 arc seconds spatial resolution and were clipped to the extent of the study area $(41.5-45.0 \mathrm{~N} ; 8.5-14.5 \mathrm{E})$. To eliminate spatial collinearity among predictors, a Pearson's correlation matrix was calculated in R 3.6.1 (R Core Team, 2019). For each pair of correlated variables $(|r|>0.7)$, the one believed to be more relevant (according to the biology of $R$. temporaria) was retained. This resulted in the selection of the following variables: Bio8 (mean temperature of the wettest quarter); Bio10 (mean temperature of the warmest quarter); Bio16 (precipitation of the wettest quarter); Bio18 (precipitation of the warmest quarter); aspect; slope; distance from water sources; vegetation and land cover (20 classes). A total of 30 replicates were computed in MaxEnt (default settings), each with $70 \%$ of data points randomly used for training and $30 \%$ for

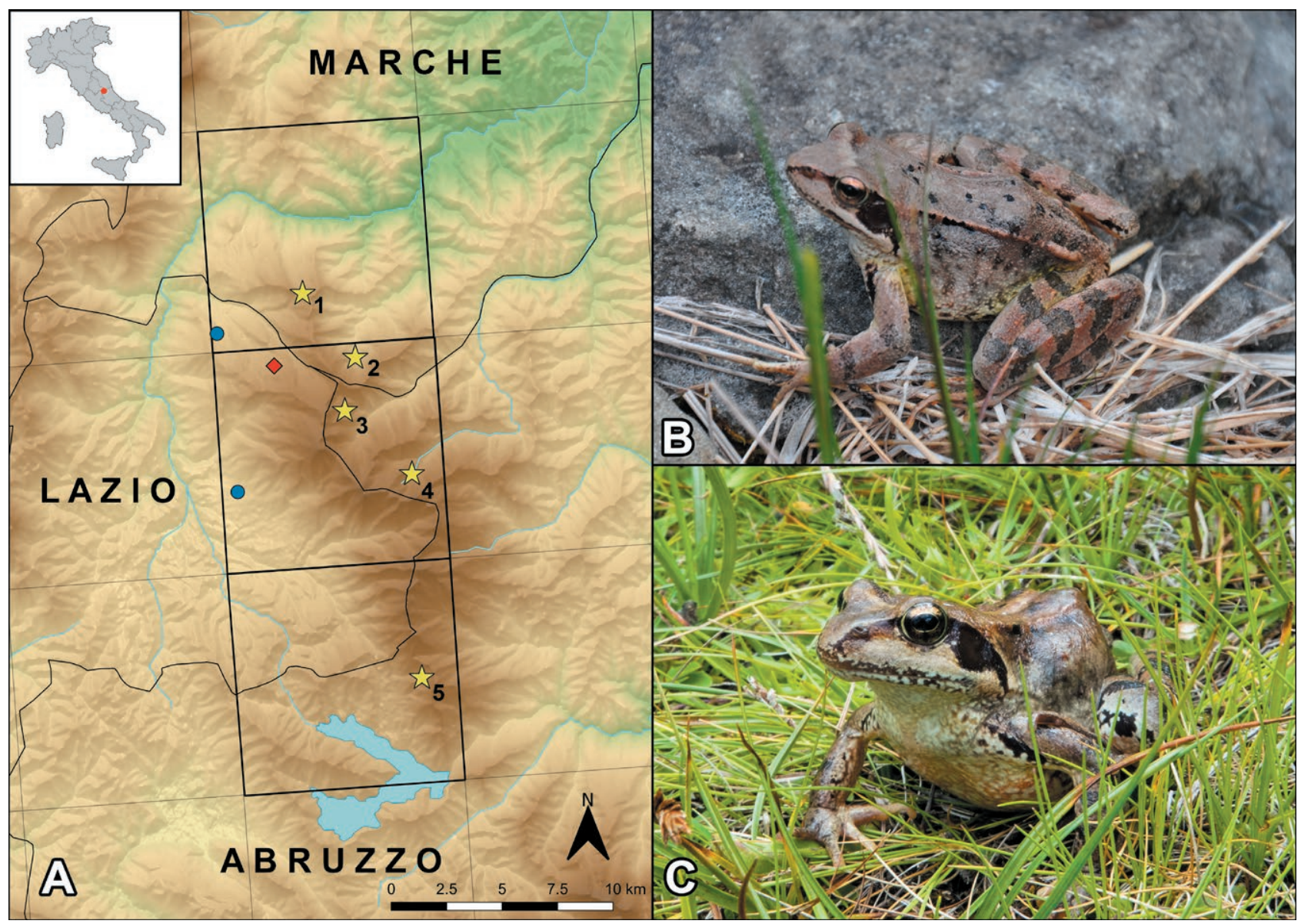

Fig. 1. A) Updated distribution of Rana temporaria in Central Italy: Agro Nero (red diamond), reports from Bruni et al. (2016) (blue circles), new data from the present study (yellow stars, numbers refer to Table 1). B) Adult individual from Valle Castellana (TE). C) Adult individual from Campotosto (AQ). 
model validation. Jackknife analysis was applied for estimating relative contribution of each predictor to the final model. Model performance was evaluated based on average omission rate and area under curve (AUC) statistics. AUC is a measure of the model's discriminatory ability between presence and background points. A model with low detectability will have AUC values closer to 0.5 (indicating no greater fit than expected by chance), whereas a model with high detectability will have values closer to 1.0 (indicating perfect model fit) (Elith et al., 2006). The average model prediction was used to produce the habitat suitability map for $R$. temporaria. The occurrence data were also used to perform a geological analysis of the substrates, intersecting the coordinates with the Italian Geo-Lithologic Map layer (http://wms.pcn.minambiente. it) in QGIS.

Rana temporaria was found in 5 new localities (Table 1 ), which represent the first observations of the species for Marche and Abruzzo (Table 1; Fig. 1).
The species distribution model indicates that around $25 \%$ of the studied area is considered suitable for the species (Fig. 2). This is mostly concentrated around the Apennines, with suitability values increasing at higher altitudes. Mean temperature of the warmest quarter (Bio10) was by far the most important predictor (57.8\% contribution), followed by mean temperature of the wettest quarter (Bio8; $17.2 \%$ ), precipitation of the wettest quarter (Bio16; 8.0\%) and precipitation of the warmest quarter (Bio18; 5.8\%). Land cover was the most relevant ecological variable (4.7\%), whether vegetation (2.6\%), aspect (1.6\%), distance from water $(1.2 \%)$ and slope $(1.1 \%)$ showed low contribution to the model. The average AUC for 30 replicated runs was $0.975 \pm 0.005$, indicating high model performance in predicting the species occurring pattern. Accordingly, test omission rate was consistently lower than what expected by chance ( $\mathrm{P}<0.001$ for all replicates).

Results from geo-lithological analysis (Fig. 3) show that 42 of 49 points (86\%; Tosco-Emiliano and central

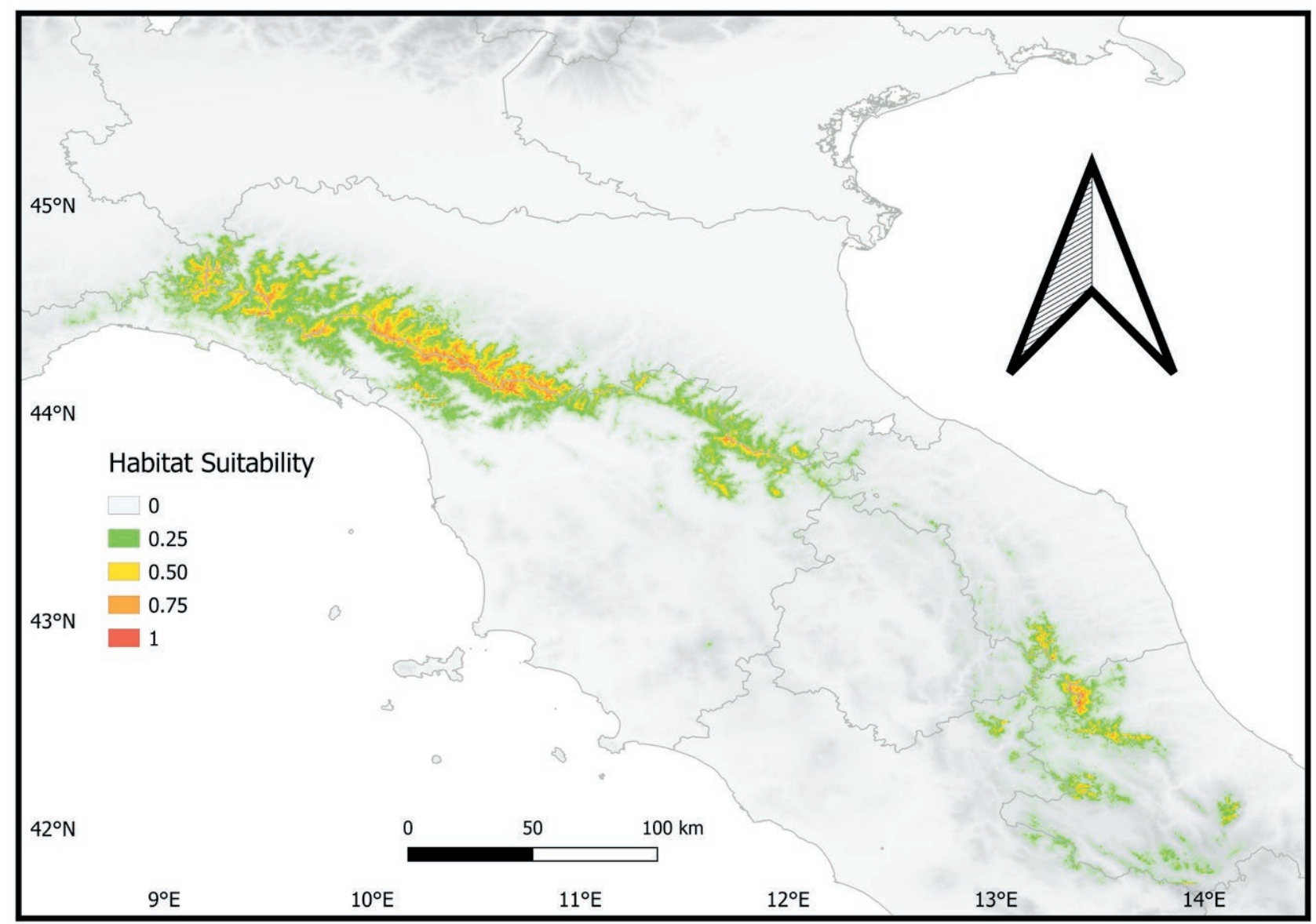

Fig. 2. Species distribution modelling for Rana temporaria in the northern and central Apennine region based on maximum entropy algorithm (MaxEnt 3.4.0; Philips et al., 2006). Warmer colours indicate higher habitat suitability. 


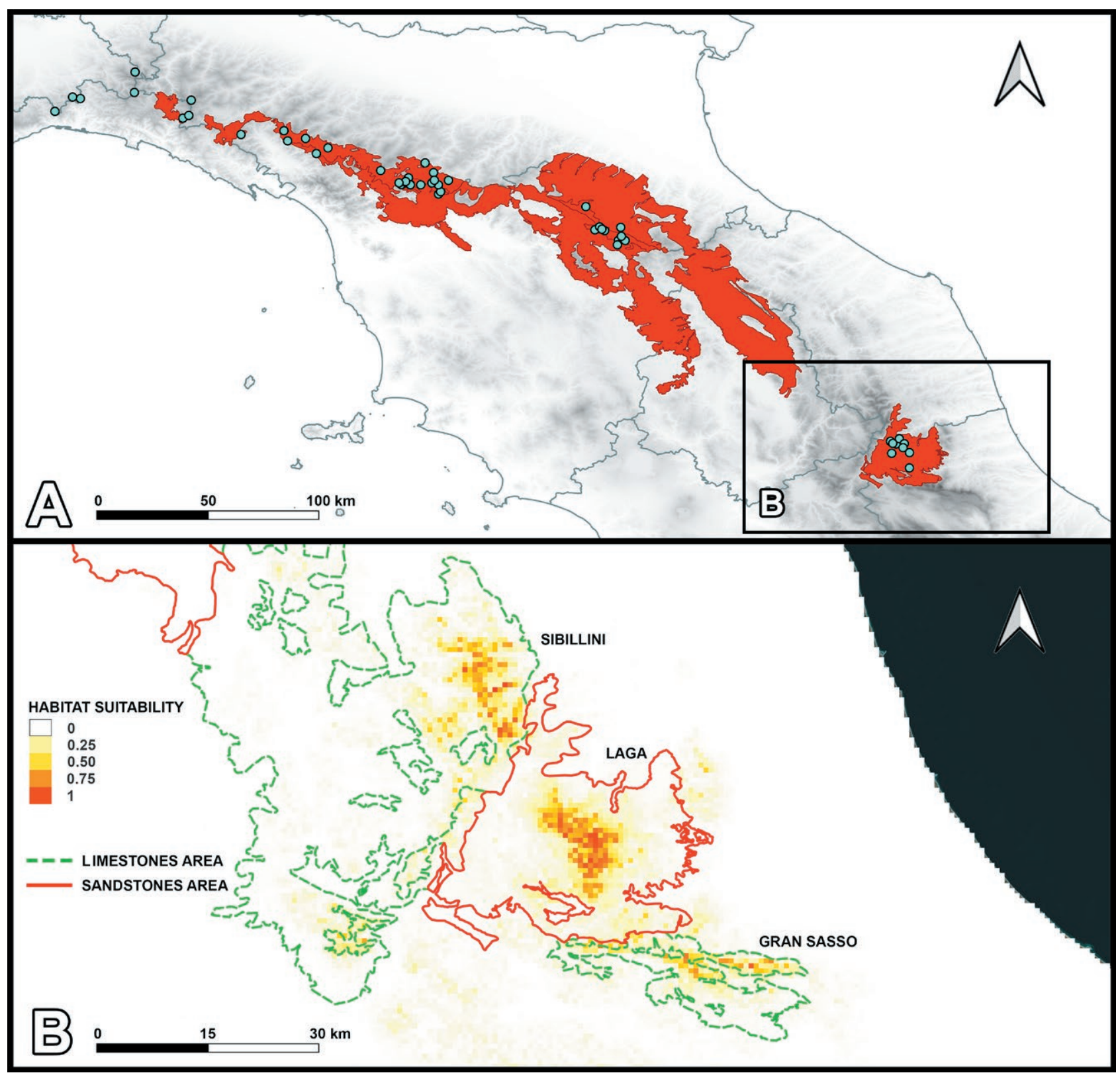

Fig. 3. Graphical results of geo-lithological analysis. A) Presence of sandstones areas (red) in northern and central Apennines and observations used for the analysis (dots). B) sandstones areas (continuous red lines) and limestones areas (dashed green lines) in central Apennines.

Apennines) are located on substrates mainly composed of sandstones, such as pelitic-arenaceous hills and mountains with parental material defined by undifferentiated tertiary sedimentary rocks. The other 7 points $(14 \%$; Liguria and Tosco-Emiliano Apennines) are located on more heterogeneous substrates, mostly on calcareousmarly reliefs (limestones) and metamorphic reliefs of basic and ultrabasic rocks.

The new records reveal that $R$. temporaria is far more widespread on Monti della Laga than previously known.
The old and new occurrences for the species in Central Italy are located inside the Gran Sasso and Monti della Laga National Park. Besides the confirmation of the presence of $R$. temporaria in the $10-\mathrm{km}$ square $33 \mathrm{~T}$ UH63 (Bruni et al., 2016), the record near Campotosto (AQ) in the 10-km square 33T UH61 represents a new national atlas square for the species (Bernini and Razzetti, 2006), and the new southern latitudinal limit in the Italian Peninsula (Fig. 1).

The habitat suitability map (Fig. 2) shows that the uplands of the Apennines harbour suitable environmen- 
tal conditions for $R$. temporaria. Interestingly, a suitability gap is present between the northern and central Apennines, reflecting the fragmented distribution of the species (Bernini and Razzetti, 2006). The contribution of mean temperature and precipitation of the warmest and wettest quarter on the species distribution model can be explained by the fact that these parameters influence the reproductive success $R$. temporaria, which breeding sites frequently consist of sun-exposed seasonal pools, especially in the study area (Cammerini, 2020; Authors, pers. obs.). However, according to the model, suitable environmental conditions are also present within the Monti Sibillini and Gran Sasso massif, areas where $R$. temporaria has never been observed. When considering geological features, it is noticeable that $86 \%$ of the occurrence records of $R$. temporaria on the Apennines are situated on sandstone substrates, the principal rock type of Monti della Laga, whereas only 14\% occurs on limestones (Fig. 3). Monti Sibillini and Gran Sasso massif featuring mainly the latter, the formation of breeding pools and their hydroperiod might be amongst the factors explaining the absence of $R$. temporaria from these karst areas. Pleistocene fossils of $R$. temporaria were found on Apuan Alps (Bartolini et al., 2014), a karst mountain chain adjacent to the northern Apennines and composed mainly of limestones, where the species does not occur nowadays (Vanni and Nistri, 2006). Since in our model the Apuan Alps resulted currently suitable for the species, it is possible that $R$. temporaria was not able to survive warm periods at higher altitudes due to the unfavourable conditions determined by the type of substrate.

Since $R$. temporaria can be quite cryptic (e.g., Marino et al., 2020), the present study highlights the need for further investigations aimed at assessing its actual distribution in Central Italy. In-depth research about size and structure of the (meta-) populations, gene flow among them and local environmental preferences would be pivotal to guide proper conservation measures in view of future climate change, since frigophilous species limited to isolated mountain ranges are among the most threatened of extinction (Blank et al., 2013).

\section{ACKNOWLEDGEMENTS}

We thank Angelo Cameli and Luciano Di Tizio for comments and suggestions; Alessandro Cameriere, Davide Ferretti and Simone Forno for their help in field research; Giovanni Rossi, Giancarlo Tondi, Alex Borrini and Matteo R. Di Nicola for observations and data; Federico Banfi for graphic help with Figure 1.

\section{REFERENCES}

Ambrogio, A., Mezzadri, S. (2018): Rane rosse d'Italia / Brown frogs of Italy. Gavia Edizioni, Piacenza.

Bagnaia, R., Catonica, C., Bianco, P.M., Ceralli, D. (2015): Dati del Sistema Informativo di Carta della Natura Carta degli Habitat alla scala 1:25.000 del Gran Sasso e dei Monti della Laga, ISPRA.

Bartolini, S., Cioppi, E., Rook, L., Delfino, M. (2014): Late Pleistocene fossils and the future distribution of Rana temporaria (Amphibia, Anura) along the Apennine Peninsula (Italy). Zool. Stud. 53: 1-10.

Bernini, F., Razzetti, E. (2006): Rana temporaria Linnaeus, 1758. In: Atlante degli Anfibi e dei Rettili d'Italia - Atlas of Italian Amphibians and Reptiles, pp. 368-373. Sindaco, R., Doria, G., Razzetti, E., Bernini, F., Eds, Edizioni Polistampa, Firenze.

Blank, L., Luoto, M., Merilä, J. (2013): Potential effects of climate change on the distribution of the common frog Rana temporaria at its northern range margin. Isr. J. Ecol. Evol. 59: 130-140.

Bruni, G., Novaga, R., Fiacchini, D., Spilinga, C., Domeneghetti, D. (2016): Updated distribution of Hydromantes italicus Dunn, 1923 (Caudata Plethodontidae): a review with new records and the first report for Latium (Italy). Biodivers. J. 7: 347-352.

Cameli, A., Di Toro, F., Brugnola, L., Di Francesco, N., Di Tizio, L., Ferri,V. (2015): Atlante erpetologico della Provincia di Teramo tra conferme e nuove segnalazioni. In: Atti X Congresso Nazionale della Societas Herpetologica Italica (Genova, 15-18 ottobre 2014), 235241. Doria, G., Poggi, R., Salvidio, S., Tavano, M., Eds, Ianieri Edizioni, Pescara.

Cammerini, G. (2020): Monitoraggio sulla presenza di Rana temporaria nel comprensorio dell'Oasi WWF di Lago Secco. Report.

Capula, M., Bagnoli, C. (1982): Il Triturus alpestris (Laurenti) e la Rana temporaria (Linnaeus) nell'Appennino centrale. Bollettino del Museo Civico di Storia Naturale, Verona, 9: 333-344.

Dufresnes, C., Nicieza, A.G., Litvinchuk, S.N., Rodrigues, N., Jeffries, D.L., Vences, M., Perrin, N., MartínezSolano, I. (2020): Are glacial refugia hotspots of speciation and cytonuclear discordances? Answers from the genomic phylogeography of Spanish common frogs. Mol. Ecol. 29: 986-1000.

Elith, J., Graham, C.H., Anderson, R.P., Dudík, M., Ferrier, S., Guisan, A., Hijmans, R.J., Huettmann, F., Leathwick, J.R., Lehmann, A., Li, J., Lohmann, L.G., Loiselle, B.A., Manion, G., Moritz, C., Nakamura, M., Nakazawa, Y., Overton, J.McC.M., Townsend Peterson, A., Phillips, S.J., Richardson, K., Scachetti- 
Pereira, R., Schapire, R.E., Soberón, J., Williams, S., Wisz M.S., Zimmermann, N.E. (2006): Novel methods improve prediction of species' distributions from occurrence data. Ecography 29: 129-151.

Gasc, J.P., Cabela, A., Crnobrnja-Isailovic, J. (1997): Atlas of amphibians and reptiles in Europe. Societas Europaea Herpetologica, Bonn.

GBIF Secretariat: GBIF Backbone Taxonomy. https://doi. org/10.15468/dl.rmhapg Accessed via https://www. gbif.org/species/2426805 [accessed on 23 Sep 2020]

Marino, D., Crottini, A., Andreone, F. (2020): Confirming Lessona's brown frogs distribution sketch: Rana temporaria is present on Turin Hills (Piedmont, NW Italy). Acta Herpetol. 15: 125-128.

Phillips, S.J., Anderson, R.P., Schapire, R.E. (2006): Maximum entropy modeling of species geographic distributions. Ecol. Model. 190: 231-259.

Posillico, M., Brugnola, L., Cameli, A., D’Amico, M., Ferri, V., Pellegrini, M., Pinchera, F. P. (2017): Atlante erpetologico della provincia de L'Aquila. In: Atti XI Congresso Nazionale Societas Herpetologica Italica (Trento, 22-25 settembre 2016), pp. 99-106. Menegon, M., Rodriguez-Prieto, A., Deflorian, M.C., Eds. Ianieri Edizioni, Pescara.

R Core Team (2019): R: A language and environment for statistical computing. R Foundation for Statistical Computing, Vienna, Austria. URL: https://www.Rproject.org/.

Razzetti, E., Zanghellini, S., Bernini, F. (2007): Rana temporaria Linnaeus, 1758. In: Fauna d'Italia, Vol. XLII Amphibia, pp. 417-424. Lanza, B., Andreone, F., Bologna, M. A., Corti, C., Razzetti, E., Eds, CalderiniEdizioni de Il Sole 24 Ore SpA, Bologna.

Stefani, F., Gentilli, A., Sacchi, R., Razzetti, E., PellitteriRosa, D., Pupin, F., Galli, P. (2012): Refugia within refugia as a key to disentangle the genetic pattern of a highly variable species: the case of Rana temporaria Linnaeus, 1758 (Anura, Ranidae). Mol. Phylogenetics Evol. 65: 718-726.

Tiberti, R., von Hardenberg, A. (2012): Impact of introduced fish on common frog (Rana temporaria) close to its altitudinal limit in alpine lakes. Amphib-reptil. 33: 303-307.

Vanni, S., Nistri, A. (2006): Atlante degli Anfibi e dei Rettili della Toscana. Regione Toscana. 